\title{
PENETRATING AMERICAN FEMALE GAZE IN THE OTTOMAN EMPIRE: A 19TH CENTURY TRAVELOGUE
}

\section{Cansu Özge ÖZMEN³}

Öz: Eski Dünya'yla ilgili Amerikan İç Savaş öncesi yazılan seyahatnameler emsallerine kıyasla çok daha azdır. Edebiyatta Amerikan Rönesansı bağımsız bir Amerikan ulusal karakteri yaratmaya çalıştığı, yazarlığın başlı başına bir meslek olarak algılanmadığı ve kadınların sanatsal ifadelerinin nadir görüldüğü ve onaylanmadığı bir zamanda, Sarah Rogers Haight'in okuyucusuna cürekat görünmemek adına "Yazar, bu mektupların halka ulaşması konusunda oldukça isteksiz olarak razı oldu" diye seslenmesi şaşırtıcı değil. Ulus olarak Eski Dünya'yı keşfetmekte geç kalan Amerikalı yazarlar seyahatnamelerinin önsözlerinde anlatıların orijinalliğini iddia ederek Amerikan orta sınıf okurlarını Amerikan seyahatnamelerini İngiliz seyahatnamelerine tercih ederek doğru karar verdikleri konusunda ikna etmeyi amaçlarlar. Bu bağlamdaki orijinallik, İngiliz seleflerinden farklılığı vurgular. Haight'in mektuplarını yayınlamakla ilgili motivasyonlarından söz ettiği girizgahı ise mahcup ve ketumdur. Bu çalışma, Amerikan İç Savaşı öncesinde Şark'ı ve özellikle Osmanlı İmparatorluğu'nu konu alan ve bir Amerikalı kadın tarafından yazılan tek seyahatnameyi inceler. Coğrafi sınırlamanın önemi Şark'la ilgili alışılagelmiş söylemsel stratejilerin Haight'in anlatısı özelinde altık kimliğin yarattı̆̆ çatışmaları üzerindeki etkisini sorgular. Haight, 19. yüzyıl Amerikan toplumundaki cinsiyet ayırımını ve kadının eve ve aileye ait rolünü aristokrat erkeğin etkinlik alanı olan keşif ve seyahate taşırken bu altık kimliği yeniden şekillendirir. Anlatısı evkamusal alan sınırlarını aştıktan sonra temsillerini ülke sınırları dışına da çıkararak daha sonra Doğu'yu ziyaret edecek olan kadın yazarlara da öncülük edecektir. $\mathrm{Bu}$ öncül rolü benimsemeyişi ve seleflerinin anlatılarından uzun alıntılar yapışı Amerikan seyahat yazınında bir emsal teşkil etmesine engel değildir.

Anahtar Sözcükler: Seyahatname, Şarkiyatçılık, Amerikan Rönesansı, Altık Kimlik.

${ }^{3}$ Yrd. Doç. Dr., Namık Kemal Üniversitesi, Fen-Edebiyat Fakültesi, İngiliz Dili ve Edebiyatı Bölümü. cozmen@nku.edu.tr 


\section{Introduction}

Antebellum American travel narratives of the Old World are rare compared to their European counterparts. At a time when American literary renaissance is pursuing a distinct American national character in American literature, authorship not yet a profession to live on alone, and artistic expressions by women uncommon and frowned upon, it is not surprising for Sarah Rogers Haight to begin her notice to the reader with "It was with extreme reluctance that the author of the following letters consented, in the first instance, that they should appear before the public..." (Haight, 1840, p. ii) to escape perceived impudence.

Belonging to a nation of quite belated travelers particularly with regard to the Orient, it is common practice for male American authors to claim originality of their accounts in their prefaces to provide a reassurance for American middle class readership of their preference of their works over the English whereas Haight's notice is apologetic and reticent about her motivations for publication. This paper seeks to scrutinize the agency of American authorship in the only travel narrative of the Ottoman Empire by an American woman published in the Antebellum period in the United States. The significance of the geographical denotation is the habitual discursive strategies applied when dealing with the Orient and to determine how Haight dealt with the conflicting notions of being and at the same time depicting the subaltern by "using the sense of sight to gain information is a classic male aristocratic technique, which avoids interaction or any kind of emotional or bodily engagement" (Harris, 2005, p. 123) which she could not partake in by virtue of being segmented along the gender identification lines at home and in her destination.

\section{Domesticity and Foreign Travel}

A secondary point of interest is the female subjectivity and authorship in tackling the notion of domesticity and how it extends to foreign travel. Domestic in Haight's case could be defined "in intimate opposition to the foreign. In this context domestic has a double meaning that not only links the familial household to the nation but also imagines both in opposition to everything outside the geographic and conceptual border of the home" (Kaplan, 1998, p. 581). Foreignness of the geographical location converges with the male predomination in act of travel and travel writing in general. Haight's awareness of this convergence is constantly pronounced throughout the narrative by her recurrent references to what she deems as more able precedents to herself and her inclusion of her husband's accounts -also the president of American Oriental Society- in her personal letters to her friend. Although the familial household is left behind, the male company led by her husband provide her with daily necessities which they brought with them from the United States and Europe in order to maintain her sense of comfort in faraway lands and particularly the East. Thus the authenticity she reflects is always accompanied by a touch of the familiar and the dangers that the company faces during their 
travels, a sense of safety. In other words, her domestic, national subjectivity remains intact during her journeys since she performs her civilizing influence in the East and feminizing influence in act of foreign travel. It is only temporarily that she senses a shift in her thought processes bred by partaking in an essentially male activity.

The occupation of constant travelling induces in one such a business habit, such a straightforward march of thought and action, that embellishment of style and choice of words in conversation or in writing are as little heeded as those peculiar comforts and elegances which attend a more settled and permanent mode of life. I have had much roughing work for some months past, and have still the same before me for a long time to come; you must not wonder, therefore, if my familiar communications to you have gradually lost their former feminine character, and finally put on the masculine garb of a traveler by profession, in place of the more graceful habit of a female tourist (Haight, 1840, p. 51).

By referring to the commonly made distinction between the tourist and the traveler, she inadvertently reveals the reason for the relative absence of women as contributors to the genre. Since travel as an act and journey narrative as a motif in American history was pioneered by man for the purposes of knowledge and land acquisition, a woman's participation succeeded the man's, continuing her confinement to the domestic sphere. Here the dichotomy of the tourist and the traveler also corresponds to the hierarchy between a superficial observer whose framework remains to be the point of departure and the ardent adventurer passionate for an authentic experience. A traveler's involvement in the cultural world of his destination according to Buzard is a proto-etnographic exercise.

At the heart of this new method lay the desideratum that the fieldworker should undergo a transformation of perspective, moving from a point of view from which the other people's customs appeared mystifying or even barbarous to something approximating the insider's or the native's point of view. Looked at from such a vantage, those strange ways came to make their own kind of sense: they joined together with every other element of the people's social world to constitute the distinctive totality of their "culture"-in the small-c, pluralizable sense of that term (Buzard, 2010, p. 7).

Haight's own definition of her state of mind which she equates with that of a traveler is the controlled manner which the men in her company deal with various challenges and frustrations that accompany any journey in the 19th century. The perspective of a proto-etnographic exercise would require an ideological shift belated American travel writers who inherited their representational tactics from their British and French counterparts could not afford. They needed to establish a distinct national identity and singular discursive tools to portray the other. Still, particularly European travel determined their collective attitude "towards their heritage, and in the end travel helped them, through learning from the experience, to respect European achievements without accepting the ruin and decay associated with them. This balance was fragile but, emotionally and ideologically, safe for an everdeveloping fragile national identity" (Melton, 1999, p. 211). 
Haight feels this transition from the female tourist to the male traveler as journey becomes the party's constant. It is however not a transformation or a new natural state of being for the female tourist rather only a garb to be taken off once traveling comes to an halt. She makes it clear that the experince is not only temporary but it is not to be repeated on her own accord. "I must therefore take example from the gentlemen, who bear their disappointment manfully; yet, as for them, they can accomplish that journey at any other time; but when once I get home again, not all the 'gardens of Gul' nor the 'vale of Cashmere' would induce me again to leave it to revisit the East" (Haight, 1840, p. 36). She does not claim the genre for herself which remains to belong in the masculine sphere. Aside from the general professed humility on her part, this is another instance where she creates demarcations between male and female travelers. Although she did not initially intend her epistles to be published, her intimate tone generally is overcast by a professional one equidistant from her object of description and the reader.

Another transitory state Haight finds herself in is a temporary reappropriation of the traveler's expectations which for her takes place in Constantinople. More significant than her descriptions of her own mental meanderings is the way she assigns common characteristics to be inhabitants of the city. "I felt the full force of the old saw that says, when in Turkey one must do as Turks do, and I am now beginning to lose my national importance and impatience, and am becoming as resigned and apathetic in matters of discomfort and inconvenience as the most devoted follower of the Prophet" (Haight, 1840, p. 36). Although she expresses the pride she feels in being a Christian throughout her journey -most of her letters end with a note on how grateful she is to God for her endeavors and prays for further protection in the face of dangers faced daily in Heathen landshere we witness her juxtaposing the American national character presumably one of agility and quickness of wit as opposed to assigned Islamic character of unquestioning obedience and sluggishness. All the characteristics of the inhabitants of Constantinople find their repercussions in the wider framework of latent Orientalist discourse which she adopts as she formulates her own identity as an American female author of travel.

As a New York socialite, she embraces the opportunity to partake in a Grand Tour of Europe and the Holy Land which is considered to be an integral part of a man's formal education. Her preparation in advance of the journey accompany her narrative with facts and figures and historical accounts of the lands they travel through. At the expense of sounding interminable and repetitious she cites other travelers only to interject apologetically for not providing in her correspondense what she imagines to be expected from a female author.

But, as we ladies can never be freemasons, why need you or I care any more about this proud trophy of theirs, than whether their charter dates from the Jews, or had its origin (as I believe) with the far more ancient Pelasgi; or whether the first royal arch commander of their tribe was a Cyclops or a Solomon? I think I hear you say, away with all such has bleu-ism, and talk to me rather of shawls 
and robes, turbans and slippers, pearls and emeralds. Talk of Circassians and Georgians, hareems and baths, sherbets and sweetmeats, pipes and coffee. I would reply to your impatience by desiring you to wait until I get farther into the East, and become more familiar with those sweet appliances of Oriental luxury (Haight, 1840, p. 64).

Orient, holding a special place in the Western imagination has functioned as a cultural space without definite borders on which national identities and agendas were enacted for centuries. Americans practiced similar discursive preferences as belated travelers to the East albeit displaying more anxiety of influence as well as latent Orientalism. This latent Orientalism revealed inherited preconceptions about the otherness of the Orient most specifically its backwardness and static nature. Most American travelers professed originality in their prefaces however failed to deliver on their promise when they were tempted to include a Eurocentric racial hierarchy, Oriental motifs of splendor, reflections on binary oppositions of ignorance and civilization in their narratives. Haight's claim on the other hand, was an awareness of what is expected of a woman to recount, with interjections of hesitations to meet those expectations such as "it would be altogether superfluous to waste your valuable time in repeating over, in my hurried and discursive manner, that which you can at any moment find so much better done by abler pens than mine" (Haight, 1840, p. 34).

\section{European Literary Influence}

Despite her hesitations, she provided a comprehensive description of the conditions of each journey as well as those who accompanied them. Her anxiety of influence was prevalent as she referred to "recollections of poetry and romance, reminiscences of Moore, Byron, and Scott," revealing hers was an anxiety that exceeded that of an American author. She had a whole white Anglo-Saxon tradition to compete with which she did tackle in her depictions but not her professions about the subject. As she remarks after quoting Vivant Denon, the French author and archeaologist "I have brought these witnesses into court (who, doubtless, are quite familiar to you) to prove the truth of my first assertion, and also, from their testimony, to frame an excuse for not entering into as much detail as you might desire on this interesting subject" (Haight, 1840 , p.192). Her reticence is limited to such claims she includes throughout her account but does not cover her recorded observations as she defines herself: "not an aspirant for the honours of authorship, sensible that my powers are not adequate to do justice to the ample store of materiel which I have gathered..." (Haight, 1840, p. 238).

Their access to accomodation and introduction to Western families residing in the Middle East was made possible by the letters of recommendations that they brought with them. This ease was challenged by the quarantine laws in various countries and the cholera epidemic in the Mediterranean in the 1830s. The itinerary and the travel arrrangements left primarily to the male company, she can spare ample amount of time to revisit the scenes in her imagination by 
recording her impressions in her letters. Sometimes her impressions gain a dream-like quality in order to complement the Oriental atmosphere which she feels indebted to impart to her reader. As her primary impressions do not approximate those of Arabian Nights, yet only of a reflection of its former glory, she often divulges sentiments of horror and depicts Gothic scenes of Egypt. She instrumentalizes the motifs of the Gothic genre by a sense of omnipresence such as an ability to experience the past and the present of Egypt at the same time revealing the impression that a dazed trance would be the only gateway to an authentic experience.

Pouring forth from the sacred gate, and passing the palace of Pharaoh, the loud wailings for the drowned host first met their ear. All Memphis joined in the deep lament, while each family, bearing a corpse, mingled in the throng, which filled the sacred way to Egypt's tombs. Like a mighty, rushing wind, I fancied those awful sounds came swelling onward, until in the hollow caverns beneath me they reverberated in loud and appalling echoes. Like a mighty, rushing wind, I fancied those awful sounds came swelling onward, until in the hollow caverns beneath me they reverberated in loud and appalling echoes (Haight, 1840, p. 141).

A disappointment in encountering the present day Orient and the imaginary preconception of its past usually leads to an embittered view about Oriental inhabitants. Since the American national character is reflected in a non monolithic manner, it is important to analyze in a genre which epitomizes the American historical experience from very early on in the way it exposes multitudes of identities. The main question then becomes: Can American travel literature reveal the diversity and clashes upon which its political and historical values were established or does it exclude the diversity it sought to eliminate or suppress? According to Melton, travel narratives never lost their function of national reassurance regardless of the destination of the journey: "It seems the beaten path could always stand another traveler, another writer, even if offering the same basic perception. Perhaps readers valued a "new" travel book not for its ability to be new at all but to reaffirm long-held, comfortable beliefs" (Melton, 1999, p. 212). In Haight's narrative, as I have already referred to, a duality if not a contradiction unfolded as she grappled with her inexpertise with authorship, her transference of authority of discourse to her husband by quoting his narrative at length within hers, what she conceived to be the female readership's expectations of her, and the inheritance of an habitual discourse which she allows herself to opt out for, instead of attempting at originality. As hers is the first Oriental travel account written by an American woman, her discursive preference gains additional importance as she is setting a precedent in a genre that is predominantly shaped by men. 1830s was a decade during which steamship travel across the Atlantic had not yet become common and affordable to the middle class Americans and although there were women who had visited the Orient before she did, noone had yet published a travel account. In Egypt before entering Aswan, Haight is overtaken by a longing for home and what it represents: absolute safety. She is fatigued by repeated risks and dangers which always seem to be close enough to disrupt comfort but far enough to 
never physically encounter. She begins imagining home as a sacred shrine and visualizes a scene native to both Nubia and the United States. "Should, perchance, an Indian be seen gliding past in his canoe, or stealing his way among the trees, then indeed would the illusion be complete; and the swarthy son of Shem, like the Nubian on his raft of reeds, or sauntering among the columns of Philae's ruins, would, by adding reality to fancy, give the last finishing touch to the picture" (Haight, 1840, p. 171). The Nubian whose "physiognomy the very counterpart of all the ancient statues, and the colour of the early race of Egypt as depicted in their tombs" brings to her mind the only other noble savage figure she has been familiarized with: the Native American. Aside from this picturesque portrayal, the local natives only contribute to the American cultural imaginary if they resemble an ancient rendition of themselves.

American Board of Commissioners for Foreign Missions was founded in Boston in 1810 initially with the purpose of converting Indians and Catholics on the American continent to Protestantism. Following a decision taken in 1818, first two American missionaries Levi Parsons and Pliny Fisk were sent to Palestine, then in the Ottoman Empire. As conversion from Islam was punishable by death, so the American missionaries soon learned to focus their efforts on nonProtestant Christian Armenians, Greeks, and Arabs. By the time Haight arrived in Palestine, quite a few missions and schools had been established in the Middle East. A devout believer, Haight is aware of the historical ramifications of the Holy Land pilgrimage and prepares her reader for an emotionally charged experience, an opportunity she embraces most enthusiastically. Of all the novelty she has encountered thus far in her journey, she finds the spiritual effect of the Holy Land incomparable particularly to the West.

Suffice it to say, that the emotions I experienced when first I saw the cloudcapped vault of St. Paul's towering above the great Babylon of Britain, that of the noble Invalids over the proud palaces of Paris, the azure domes of St. Petersburg, the gilded crosses of Moscow, and the cloudpiercing minarets of Constantinople, all combined, were as naught compared with the intensity of feeling produced by the first view of the Holy City and its interesting environs (Haight, 1840, Vol. II, p.67).

Her reticence in describing mere historical and cultural remnants disappears in the Holy Land as she seems to regard the role of following and passing on religious practices to be a part of the female domain. Despite inclusion of extensive description of the flora and fauna, she centers her observations around the discussion of history and national memory. Challenging the authenticity of certain relics and locations, she consults various sources to escape myth-making and questions the veracity of the information bred and passed on by numerous generations. What she proposes is refraining from a "cold and stolid indifference to the exciting events which have taken place in this vicinity" and escaping skepticism which risks a danger of "confirmed infidelity" (Haight, 1840, Vol. II, p. 75). 
She shares a profound disappointment with many other Western pilgrims in what she calls the "sober realities" of the East. Filthy towns inhabited with people and improperly cultivated land. "These interactions between Protestant Americans and Arabs deeply affected the transformation of the idea of the Holy Land from a static bible illustration image to a vibrant modern mythology" (Rogers, 2011, p.61). The Western spiritual experience was disturbed by the control of the Ottoman Empire of most Christian sites. Risks of robbery and theft were imminent and distorted the dream-like quality of the journey. The mysticism that emanates from the geography for being at the core of the Muslim, the Jew and the Christian according to Haight dwindles as Muslim is destined to be excluded from God's good graces for being bloodthirsty, Jew for being stubborn and Catholic Christian for his fallacy. The Protestant Christian pilgrim however, will reflect and be humble as he takes on this great responsibility (Haight, 1840, Vol. II, p. 83).

It is initially in Constantinople that Haight touches upon the issue of slavery without any reference to its American counterpart. Her primary concern with regard to slavery is not the racial hierarchy established by a white supremacist culture but a gendered distinction where men represent the patriarchal rule and the women the commodity serving the needs of this despotic rule. Then she introduces a secondary binary of an ancient Western presence in the Orient and the Oriental neglect of a formerly blessed land now cursed by being inhabited by a subhuman species.

Yet is it not also the land where "man is a despot and woman a slave, and sold as cattle in the market-place? Is not this the land by Nature blessed beyond her pale, and where "all save the spirit of man is divine?" and yet is it not here that those blessings are least appreciated, and left to run fallow through the sheer neglect and inanity of the lazy and stupid possessors of the soil? Is not this once splendid capital of a Roman empire now the mere rendezvous of a horde of beastly Tartars? (Haight, 1840, p. 39).

Race only comes at the forefront of her narrative in a slave market in Cairo which she finds less impressive than that in Constantinople. Slaves had been brought from Niger on a trying journey and the first visual imagery aroused in Haight's mind on encountering them is that of content snakes shining under the sun. She attests to the fact that slaves indeed are also descendants of Biblical figures yet fails to form any connection between American slavery and what she witnesses in Cairo or Constantinople. Interestingly, she makes a vague reference to an evolutionary chain which links animals to humans yet this analogy is used to further evoke alienation Haight feels when faced with the people of Niger.

I have never yet seen such a hideous misrepresentation of the human form divine, as these children of Ham presented. The various degrees of form and feature, from the passably comely to the horridly ugly and disgusting, almost induced me to believe the theory which holds that there is a connected chain of animals, from the little caricature monkey of Brazil to the fierce orangoutang of the Cape, and then on through all the different phases of human nature, from the 
most deformed races of Guinea and Senegal, to the beautiful and godlike sons of Japhet, in Georgia and the Caucasus (Haight, 1840, p. 112).

\title{
Conclusion
}

Haight, in her two volumes of the Old World, provides the reader with more than a solipsistic experience with an hyperawareness of her surroundings as well as the conditions that were specifically laid out for her comfort by her male compatriots and fellow travelers. Her insightful observations about binaries such as gender and race do not extend to any criticism of domestic affairs within the United States. She displays the same vague notions of a conquest of the Old World by religion if not by military as her male precedents. Her often fragmentary and eclectic depictions tinted with a layer of daydreaming contributes to her conceptualization of the East in a duality that encourages her to make progressive suggestions to monumentalization of American history at home. Her take on the gender polarity does not display an awareness of gender politics at home which does not refrain her from criticism of patriarchal reflections in the Orient. Instead of a possible liberating impact traveling to distant lands could have, Haight is comfortably inclined to enjoy the class privilege with which she maintains a sense of peace and security.

\section{REFERENCES}

Buzard, J. (2010). Portable Boundaries: Trollope, Race, and Travel. An Interdisciplinary Journal, 32 (1), 5-18.

Haight, S. R. (1840). Letters from the Old World by a Lady of New York. Vol. I. New York: Harper and Brothers.

Haight, S. R. (1840). Letters from the Old World by a Lady of New York. Vol. II. New York: Harper and Brothers.

Harris, D. (2005). Key Concepts in Leisure Studies. London: Sage.

Kaplan, A. (1998). Manifest Domesticity. American Literature, 70 (3), 581-606.

Melton, J. A. (1999). Touring Decay: Nineteenth-Century American Travel Writers in Europe. Papers on Language \& Literature, 35 (22). 206-222.

Rogers, S. S. (2011). Inventing the Holy Land: American Protestant Pilgrimage to Palestine, 1865-1941. Lanham: Lexington Books.

\section{PENETRATING AMERICAN FEMALE GAZE IN THE OTTOMAN EMPIRE: A 19TH CENTURY TRAVELOGUE}

\begin{abstract}
Antebellum American travel narratives of the Old World are rare compared to their European counterparts. At a time when American literary renaissance is pursuing a distinct American national character in American literature, authorship not yet a profession to live on alone, and artistic expressions by women uncommon and frowned upon, it is not surprising for Sarah Rogers Haight to be reticent in her narrative. Belonging to a nation of quite belated travelers particularly with regard to the Orient, it is common practice for male American authors to claim
\end{abstract}


originality of their accounts in their prefaces to provide a reassurance for American middle class readership of their preference of their works over the English whereas Haight's notice is apologetic and reticent about her motivations for publication. This paper seeks to scrutinize the agency of American authorship in the only travel narrative of the Ottoman Empire by an American woman published in the Antebellum period in the United States. The significance of the geographical denotation is the habitual discursive strategies applied when dealing with the Orient and to determine how Haight dealt with the conflicting notions of being and at the same time depicting the subaltern by "using the sense of sight to gain information is a classic male aristocratic technique, which avoids interaction or any kind of emotional or bodily engagement" which she could not partake in by virtue of being segmented along the gender identification lines at home and in her destination.

Keywords: Travel Narrative, Orientalism, American Literary Renaissance, Subaltern. 